\title{
PERBANDINGAN PENENTUAN ANTOSIANIN PADA BUNGA ROSELLA DENGAN MENGGUNAKAN UV-VIS SPEKTROMETRI DAN PENCITRAAN WARNA
}

\author{
Hetty Nur Handayani ${ }^{1}$, Kaliawan ${ }^{1}$, Nanang Setio Pambudi ${ }^{2}$ \\ Jurusan Teknik Kimia Politeknik Negeri Malang \\ Jurusan Teknik Elektro Politeknik Negeri Malang \\ email: hetty@polinema.ac.id
}

(Artikel diterima: Oktober 2019, direvisi: September 2019, diterima untuk terbit: Januari 2020)

\begin{abstract}
Abstrak - Antosianin sebagai salah satu antioksidan banyak terdapat pada berbagai tanaman bunga dan buah. Antosianin ini berperan dalam memberikan warna merah atau ungu pada tanaman, yang salah satunya berfungsi sebagai pencegah radikal bebas. Rosella merupakan tanaman yang banyak dikonsumsi sebagai minuman seduh, mengandung antosianin yang cukup banyak. Pengujian antosianin dalam suatu sampel berdasarkan penelitian sebelumnya menggunakan spektrofotometer UVVIS dan HPLC. Pendekatan lebih sederhana dalam pengujian antosianin sebagai senyawa yang berwarna dengan menggunakan metode kolorimetri dan pencitraan warna. Dengan membandingkan dua metode pengujian yaitu spektrofotometer UV-VIS dan pencitraan warna, pengujian antosianin baik secara kualitatif dan kuantitatif bisa lebih mudah. Dari hasil penelitian menunjukkan bahwa dengan menggunakan spektrofotometer UV-VIS, pengujian dan karakterisasi antosianin dengan menggunakan metode $\mathrm{pH}$ differensial mencapai nilai koefisien korelasiyang tinggi yaitu diatas 0.995 . Tetapi nilai pengukuran ini memiliki nilai maksimal pada konsentrasi $800 \mathrm{ppm}$, diatas konsentrasi tersebut nilai absorbansi lebih dari 0.8 yang mana akan melebihi nilai transmitannya. Sedangkan pengujian dengan menggunakan pencitraan warna, pengukuran konsentrasi antosianin pada 400 ppm dengan koefisien korelasi maksimum sebesar 0.9936.
\end{abstract}

Kata kunci: Antosianin, pencitraan warna, spektrometri.

\section{Pendahuluan}

Rosella atau Hibiscus sabdariffa merupakan tanaman yang berasal dari benua Afrika. Di Indonesia, tanaman ini dikenal sebagai rosela atau asam paya. Bunga rosela dimanfaatkan sebagai minuman yang diseduh seperti teh. Rosella memiliki kandungan antioksidan tinggi yang sangat dibutuhkan untuk kesehatan. Semakin pekat warna merah pada kelopak bunga rosella, rasanya akan semakin asam dan kandungan antosianin (antioksidan) semakin tinggi. Antosianin ini berperan menjaga kerusakan sel akibat penyerapan sinar ultraviolet berlebih. Ia melindungi sel-sel tubuh dari perubahan akibat radikal bebas. Kandungan senyawa yang paling banyak pada rosella merah adalah adanya senyawa antosianin yang membentuk flavonoid yang berperan sebagai antioksidan (Haidar, 2016).

Antosianin merupakan senyawa antioksidan yang banyak terdapat pada kebanyakan tanaman berwarna. Antioksidan ini banyak memberikan manfaat pada tubuh sebagai pencegah adanya radikal bebas. Senyawa ini pada umumnya terdapat pada tanaman dengan warna ungu, merah atau biru (Koswara, 2009).

Pada $\mathrm{pH}$ rendah (asam), pigmen berwarna merah dan pada $\mathrm{pH}$ tinggi pigmen berubah menjadi violet dan kemudian menjadi biru. Konsentrasi pigmen juga sangat berperan dalam menentukan warna (hue). Pada konsentrasi yang encer, antosianin berwarna biru sebaliknya pada konsentrasi pekat berwarna merah, dan konsentrasi biasa berwarna ungu (Koswara, 2009). Selain mempengaruhi warna antosianin, $\mathrm{pH}$ juga mempengaruhi stabilitasnya, dimana dalam suasana asam akan berwarna merah dan suasana basa berwarna biru. Antosianin lebih stabil dalam suasana asam dibandingkan dalam suasana alkalis ataupun netral (Hambali et al., 2014).

Metode untuk memperoleh senyawa antosianin yang pemah dilakukan sebelumnya antara lain dengan supercritical fluid, ekstraksi air, ekstraksi pelarut organik, dan lain-lain. Cara tersebut memiliki kelebihan dan kekurangan masingmasing supercritical fluid diketahui lebih ramah lingkungan, selekfif dan cepat dalam proses ekstraksi tetapi membutuhkan tekanan yang tinggi sehingga biaya ekstraksi lebih mahal dibandingkan dengan ekstraksi pelarut biasa.(Suzery et al., 2010; Wang and Chau-jong, 2008).

Karakterisasi antosianin menggunakan spektrofotometer UV-VIS dilakukan pada pH 1 dan 4.5 pada panjang gelombang maksimum untuk antosianin dan panjang gelombang $700 \mathrm{~nm}$ untuk koreksi adanya pengkabutan pada sampel dan menggunakan blanko akuades. Dua pita absorbsi yang berbeda, satu dalam daerah UV (260 - $280 \mathrm{~nm})$ dan lainnya dalam daerah visible/tampak (490 $-550 \quad \mathrm{~nm}$ ), ditunjukkan oleh semua jenis antosianin(Wrolstad et al., 2004).

Warna sinar yang direspon oleh mata adalah sinar tampak (visible spectrum) dengan panjang gelombang berkisar dari 400 (biru) sampai $700 \mathrm{~nm}$ (merah). Warnawarna yang diterima oleh mata manusia merupakan hasil kombinasi cahaya dengan panjang gelombang berbeda. Penelitian memperlihatkan bahwa kombinasi warna yang memberikan rentang warna yang paling lebar adalah $\operatorname{red}(R)$, green $(G)$, dan blue $(B)$. Ketiga warna tersebut dinamakan warna pokok (primaries), dan sering disingkat sebagai warna dasar $R G B$. Setiap parameter ruang warna ini mewakili aspek spesifik cahaya / warna (mis. ringan, saturasi, rona). Oleh karena itu, masuk akal bahwa salah satu dari parameter tersebut mungkin berkorelasi dengan penyerapan cahaya (Haifa et al., 2011)

Pada penelitian lainnya, analisis citra digital juga digunakan dalam analisis warna dalam penentuan suatu senyawa berdasarkan warnanya. Berdasarkan penelitian 
(Rusmawan et al., n.d.) citra digital dapat digunakan sebagai alat ukur sederhana dan murah dalam analisis kuantitatif dengan metode kolorimetri.

Tabel 1. Nilai absorbansi antosianin pada sampel

\begin{tabular}{|l|c|r|r|r|l|}
\hline \multirow{2}{*}{$\begin{array}{l}\text { Kons } \\
(\mathrm{ppm})\end{array}$} & \multicolumn{2}{|l|}{$\mathrm{pH}=1$} & \multicolumn{2}{l}{$\mathrm{pH}=4,5$} \\
\cline { 2 - 5 } $\mathrm{N}$ & $510 \mathrm{~nm}$ & $700 \mathrm{~nm}$ & $510 \mathrm{~nm}$ & $700 \mathrm{~nm}$ & \\
\hline 25 & 0.033 & - & 0.007 & 0.001 & 0.027 \\
\hline 50 & 0.054 & - & 0.009 & 0.003 & 0.048 \\
\hline 100 & 0.114 & 0.001 & 0.020 & 0.005 & 0.098 \\
\hline 200 & 0.228 & 0.004 & 0.039 & 0.009 & 0.194 \\
\hline 400 & 0.474 & 0.014 & 0.085 & 0.019 & 0.394 \\
\hline 800 & 0.957 & 0.035 & 0.186 & 0.037 & 0.773 \\
\hline 1000 & 1.176 & 0.049 & 0.263 & 0.049 & 0.913 \\
\hline
\end{tabular}

\section{METODE PENELITIAN}

Penelitian dilakukan di laboratorium Analisis Instrumentasi Jurusan Teknik Kimia Politeknik Negeri Malang.

Bahan yang digunakan dalam penelitian ini adalah bunga rosella kering, yang kemudian dihaluskan dan diayak. Pelarut yang digunakan antara lain, metanol, $\mathrm{HCl} 1,5 \mathrm{~N}$, larutan buffer $\mathrm{pH}$ 1, larutan buffer $\mathrm{pH} 4,5$.

Perlakuan pelarutan menggunakan ultrasonic chamber selama 60 menit, kemudian disaring dan dipekatkan dalam oven pada suhu $40^{\circ} \mathrm{C}$. Ekstrak yang diperoleh, kemudian dilarutkan dalam larutan buffer $\mathrm{pH} 1$ dan $\mathrm{pH}$ 4,5 dengan konsentrasi 25, 50, 100, 200, 400, 800, 1000 ppm.

Pengujian dilakukan dengan menggunakan alat spektrofotometer UV-Vis pada panjang gelombang $510 \mathrm{~nm}$ dan $700 \mathrm{~nm}$. Pada masing-masing konsentrasi tersebut diatas, setelah dilarutkan dalam larutan buffer $\mathrm{pH} 1$ dan $\mathrm{pH} 4,5$ diukur absorbansinya pada panjang gelombang maksimum antosianin yaitu $510 \mathrm{~nm}$ dan $700 \mathrm{~nm}$.

Pengujian dengan menggunakan pencitraan warna dilakukan dengan menggunakan kamera smartphone, sedangkan sampel diletakkan dalam kuvet dan jarak pengambilan gambar sejauh $25 \mathrm{~cm}$ dari obyek. Hasil gambar yang diperoleh kemudian dikonversi ke program Photoshop untuk mendapatkan nilai L, a, b nya. Dari kedua metode tersebut dibandingkan nilai linieritasnya serta nilai batas deteksi / limit of detection (LOD) dan nilai batas kuantifikasi / limit of quantification (LOQ).

\section{HASIL DAN PEMBAHASAN}

\section{A. Pengukuran dengan Spektrofotometer UV-Vis}

Pengujian antosianin dengan menggunakan spektrofotometer UV-VIS dilakukan pada panjang gelombang maksimum untuk antosianin yaitu $510 \mathrm{~nm}$ dan panjang gelombang $700 \mathrm{~nm}$. Pada $\mathrm{pH} \mathrm{1,} \mathrm{antosianin} \mathrm{dengan}$ konsentrasi 25 ppm tidak memberikan warna jelas, sedangkan warna pink hingga merah nampak pada konsentrasi 50 hingga $1000 \mathrm{ppm}$. Pada pH 4,5, warna antosianin cenderung tidak terlalu tampak jelas, tetapi nampak pada konsentrasi yang lebih besar yaitu pada 400 ppm hingga 1000 ppm. Uji antosianin pada peralatan spektrofotometer UV-VIS yaitu mengukur absorbansi yang terbaca terhadap masing-masing konsentrasi dalam satuan ppm.

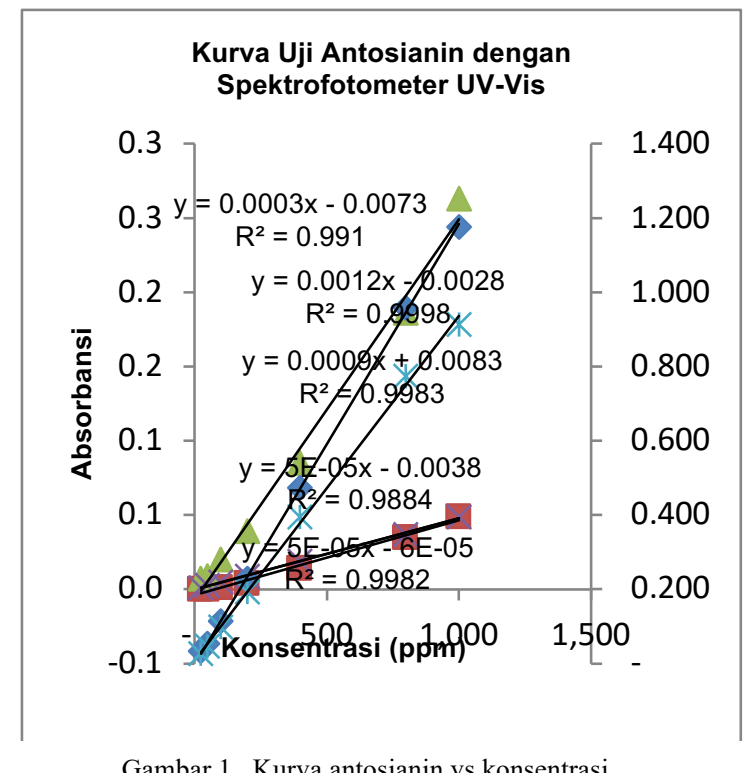

Gambar 1. menunjukkan bahwa koefisien korelasi yang sangat tinggi diatas 0.995 kecuali pada pengukuran $700 \mathrm{~nm}$ dan 510 pada $\mathrm{pH}$ 4,5. Tabel 4.1 dan Gambar 4.1 menunjukan hubungan analisis uji antosianin yang mempunyai tingkat kepercayaan sangat tinggi pada perlakuan $\mathrm{pH} 1$ pada panjang gelombang 510 dan delta (A). Konsentrasi pengujian maksimum pada 800 ppm, apabila diatas 800 ppm, maka berakibat pada absorbansi lebih dari 0,8 bahkan bisa melebihi batas maksimum absorbansi (10\% transmitan).

Berdasarkan grafik tersebut, menunjukkan bahwa uji linierisasi perhitungan keduanya mempunyai nilai slope (kemiringan) yang mendekati angka 1. Hasil linierisasi dikatakan baik jika nilai koefisien korelasi mendekati angka 1, begitu juga kemiringan menunjukkan respon yang proporsional dimana konsentrasi antosianin berbanding lurus dengan absorbansi. Adapun perbedaan terjadi pada intersep dimana pada $\mathrm{pH} 1,510 \mathrm{~nm}$ menunjukkan angka negatip sedangkan A menunjukkan angka positip, Dari perhitungan keduanya didapatkan LOD pada $\mathrm{pH} 1510 \mathrm{~nm}$ menunjukkan angka 7,787 ppm, sedangkan LOQ menunjukkan angka 25,958 ppm. Pada Perhitungan A LOD menunjukkan angka 5,733 ppm, sedangkan LOQ menunjukkan angka 19,110 ppm. Bila dibandingkan metode perhitungan keduanya, nilai A lebih baik dibandingkan dengan perhitungan $\mathrm{pH} 1,510 \mathrm{~nm}$.

\section{B. Pengukuran dengan pencitraan warna}

Uji antosianin dengan pencitraan warna yaitu dengan mengambil obyek warna dari masing-masing konsentrasi antosianin dengan foto kemudian dianalisis obyek dengan perangkat lunak Photoshop. Hasil pengujian warna yang dianalisis berupa nilai L, a dan b pada masing perlakuan sebagaimana disajikan pada Tabel 2. 
Tabel 2.Hasil Pengujian Warna dengan L a b

\begin{tabular}{|l|c|c|c|c|c|c|c|c|c|c|}
\hline \multirow{2}{*}{$\begin{array}{c}\text { Kons } \\
(\mathrm{ppm})\end{array}$} & \multicolumn{3}{|c|}{$\mathrm{pH} 1$} & \multicolumn{3}{|c|}{$\mathrm{pH} 4,5$} & $\Delta \mathrm{L}$ & $\Delta \mathrm{a}$ & $\Delta \mathrm{b}$ & $\Delta \mathrm{E}_{0}$ \\
\hline & $\mathrm{L}$ & $\mathrm{a}$ & $\mathrm{b}$ & $\mathrm{L}$ & $\mathrm{a}$ & $\mathrm{b}$ & & & & \\
\hline 25 & 66 & 1 & - & 67 & - & - & 1 & 1 & - & 1,66 \\
\hline 50 & 65 & 4 & 1 & 68 & - & - & 3 & 4 & 1 & 5,87 \\
\hline 100 & 62 & 6 & 1 & 67 & - & - & 5 & 6 & 1 & 8,59 \\
\hline 200 & 58 & 12 & 2 & 65 & - & - & 7 & 12 & 2 & 14,19 \\
\hline 400 & 52 & 22 & 6 & 63 & 2 & - & 11 & 20 & 6 & 19,36 \\
\hline 800 & 46 & 37 & 18 & 47 & 35 & 14 & 1 & 2 & 4 & 2,43 \\
\hline
\end{tabular}

Berdasarkan tabel 2, terjadi penurunan nilai pada konsentrasi $800 \mathrm{ppm}$ untuk semua kondisi $\mathrm{pH}$, hal ini menunjukkan batas maksimum pengukuran dengan program CieDE2000. Data hasil pengukuran ini ditampilkan dalam kurva nilai L a b dengan konsentrasi.

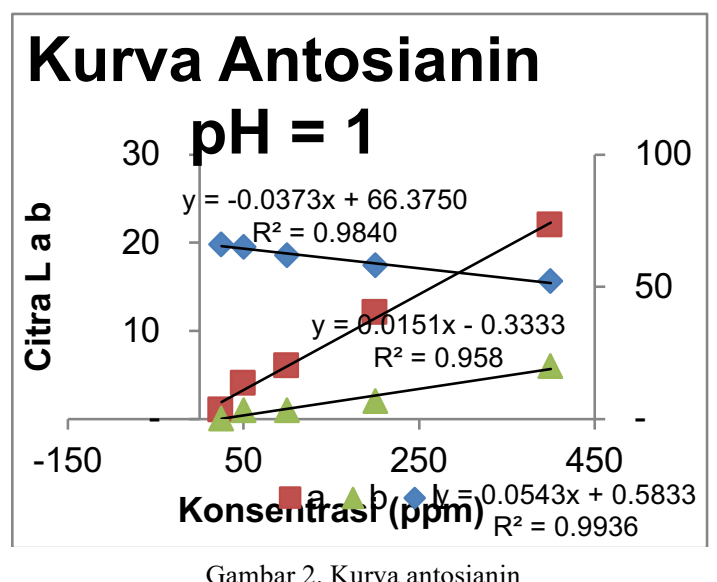

Berdasarkan kurva tersebut, nilai intensitas parameter a menunjukkan nilai terbesar yaitu 0,9936 pada konsentrasi $400 \mathrm{ppm}$. Hal ini menunjukkan bahwa pengukuran antosianin dengan pencitraan warna ini terbatas pada konsentrasi maksimum 400 ppm dan signifikan menggunakan parameter a.

\section{KESIMPULAN}

1. Pengujian antosianin dengan menggunakan spektrofotometer UV-Vis memberikan hasil yang baik jika pengukuran maksimal pada konsentrasi 800 ppm, dengan koefisien korelasi 0,995.

2. Pengujian antosianin dengan menggunakan pencitraan warna mempunyai konsentrasi maksimum pada konsentrasi 400 ppm dengan menggunakan parameter nilai a.

3. Analisis dengan menggunakan pencitraan warna untuk karakterisasi antosianin dapat dilakukan bila konsentrasi sampel tidak kurang dari 50 ppm dan tidak melebihi batas maksimum pengukuran pada $400 \mathrm{ppm}$.

\section{DAftar Pustaka}

[1] Haidar, Z., 2016. Si Cantik Rosella: Bunga Cantik Berjuta Khasiat. Edumania.

[2] Haifa, B.A., Calinici, T., Bacarea, V., Alexandru Schiopu, 2011. Comparison between Digital Image Processing and Spectrophotometric Measurements Methods. Application in Electrophoresis Interpretation. Appl. Med. Inform. 28.

[3] Hambali, M., Mayasari, F., Noermansyah, F., 2014. Ekstraksi Antosianin dari Ubi Jalar dengan Variasi Konsentrasi Solven, dan Lama Waktu Ekstraksi. Tek. Kim., 2 20, 27.

[4] Koswara, S., 2009. Pewarna Alami: Produksi dan Penggunaannya. eBookpangan.com.

[5] Rusmawan, C.A., Onggo, D., Mulyani, I., n.d. Analisis Kolorimetri Kadar Besi(III) dalam Sampel Air Sumur dengan Metoda Pencitraan Digital. Simp. Nas. Inov. Pembelajaran Dan Sains 2011 SNIPS 2011.

[6] Wrolstad, R.E., Acree, T.E., Decker, E.A., Michael H. Penner, Steven J. Schwartz, David S. Reid, Shoemaker, C.F., Smith, D., Sporns, P., 2004. Handbook of Food Analytical Chemistry: Pigments, Colorants, Flavors, Texture, and Bioactive Food sComponents, in: Handbook of Food Analytical Chemistry. John Wiley \& Sons, Inc. 